\title{
Sciendo
}

\section{Cryptocurrencies: Some Remarks from the Perspective of Polish Employment and Tax Law ${ }^{1}$}

\author{
Aneta Tyc \\ Robert Siuciński \\ The Faculty of Law and Administration, \\ University of Łódź \\ Kopcinskiego 8/12, \\ Łódź 90-232, Poland \\ Email: atyc@wpia.uni.lodz.pl \\ Email: rsiucinski@wpia.uni.lodz.pl
}

\begin{abstract}
In view of the fact that technological progress is in a constant state of change, current research efforts are directed towards blockchain technology and cryptocurrencies. Starting with the description of the way blockchain technology operates, the notions of decentralisation, proof-of-work consensus, and practical immutability are explained. Further, the article examines the possibility of using cryptocurrency in order to pay remuneration, realise partial non-cash payment of remuneration or grant an award to an employee. This article presents evidence that demonstrates that remuneration in the framework of the employment relationship in Poland cannot be paid in cryptocurrency, which contributes to the performance of the protective function of labour law. The article concludes that a collective labour agreement could include a clause allowing the employer to realise partial non-cash payment of remuneration in cryptocurrency. Similar provisions could be introduced in labour law, but the Polish legislator has never adopted such a measure. The authors highlight, however, that an award can be paid in cryptocurrency even in the full amount. Next, the authors research the new tax regulations in force in Poland since 1 January 2019 and explain why it is conceptually more convincing to classify revenues from cryptocurrency trading as revenues from money capital and revenues from capital gains than as property
\end{abstract}

TalTech Journal of European Studies (ISSN 2674-4619) is the legal successor of the Baltic Journal of European Studies (ISSN 2228-0596) and is indexed and listed in the same way in all the databases. 
rights. The article presents a definition of the disposal for valuable consideration of a virtual currency. The purpose of this article is also to study how high is the income tax on income earned from the disposal for valuable consideration of virtual currencies. Moreover, an overview of the legislation related to tax-deductible expenses is provided. Finally, some reflections on the cryptocurrency trading in the context of the pursuit of an economic activity are given. The review especially highlights the Council Directive 2006/112/EC of 28 November 2006 on the common system of value added tax, and the judgment of the CJEU of 22 October 2015 (Skatteverket v. David Hedqvist [2015], case C-264/14), which has impacted the approach to the VAT problem in Poland.

Keywords: cryptocurrency, blockchain technology, employment law, Polish law, remuneration, tax law

\section{Introduction}

The global financial crisis, which began in 2008, reduced people's confidence in financial institutions and banks. It was then that Satoshi Nakamoto introduced Bitcoin, describing it as "a purely peer-to-peer version of electronic cash" that "would allow online payments to be sent directly from one party to another without going through a financial institution" (Nakamoto, 2008, p. 1). Since then, cryptocurrencies turned out to be an invention that has revolutionised the perception of money (Malherbe et al., 2019, p. 127; Taleb, 2019, p. 48). They have proliferated rapidly and have created a lot of buzz among investors, in the financial sector and in the media. As of 14 March 2020, there are over 2,400 cryptocurrencies with a total market capitalisation of $153,612,525,021$ dollars. Bitcoin tops the podium in terms of market capitalisation (98,025,966,852 dollars), and Ethereum ranks second (14,042,916,077 dollars). (CoinMarketCap, 2020)

Bitcoin and other cryptocurrencies are based on the blockchain technology, which is also used to provide systems for the smart execution of contracts. More to the point, there are also plans to expand the blockchains network to cover public services that are currently provided by governments (Appukuttan Nair, 2019, p. 86). However, as our legislators do not keep pace with this kind of new technologies, many questions and problems can arise from the perspective of, e.g., commercial law, criminal law, civil law, tax law 
or employment law. As the issue is extremely broad, we limit ourselves to the analysis of cryptocurrency application from the point of view of the latter two branches of the Polish legal system.

Let us imagine the situation in which someone earns revenue from cryptocurrency trading in the course of economic activity, and employs a worker who is mining cryptocurrencies in the framework of an employment relationship or a services contract. Is it possible to pay remuneration in cryptocurrency and, if so, what are the taxation rules concerning the worker in such a situation? What are the taxation rules applicable to the employer? This article provides answers to these research questions.

There were two main hypotheses that guided our research. The first of these is that preventing payment of salaries in full in cryptocurrencies is an embodiment of the protective function of labour law. The second is that it is conceptually more convincing to classify revenues from cryptocurrency trading as revenues from money capital and revenues from capital gains than as property rights, so the new tax regulations in force in Poland since 1 January 2019 can be justified.

It follows from the foregoing that a hypothetical-deductive methodology is adopted, involving the formulation of hypotheses in response to the posed research problems. These hypotheses are tested through critical analysis of primary source texts (legislation) and taking into consideration the specificity of cryptocurrencies. The secondary literature is also subject to analysis and critique. It encompasses, among others, articles by English and Nezhadian (2017), Fulmer (2019), Krysiak et al. (2019), Zozaya et al. (2019), and Ruggiero (2018). The investigative technique involves building a synthesis of the accumulated literature, which is used to help determine the veracity of the research hypotheses. Besides, it is crucial in empirical legal studies to clarify the content of law itself. In this respect, an important role has been assigned to a logical-linguistic method which allows the exegesis and interpretation of the content of legal norms and the removal of emerging doubts. Moreover, an axiological method has been used in this article. The study of law in axiological terms is a consequence of understanding the law as a set of standards of conduct in relations between people, built on the basis of some values to their implementation and defence. Positive law is not only a carrier of specific values but also their guarantee. The authors refer to them in the interpretation of law.

The article is organised as follows. Part 2 explores the functioning of the blockchain technology. An understanding of this matter is necessary in 
attempting to make a legal assessment of the proposed research problems. Part 3 answers the question about the possibility of using cryptocurrency in order to pay remuneration, realise partial non-cash payment of remuneration, grant a bonus (premia) or an award (nagroda) to an employee. Part 4 focuses on the new tax regulations in force in Poland since 1 January 2019, paying special attention to revenues from cryptocurrency trading, which are classified as revenues from money capital and revenues from capital gains. Part 5 offers some concluding remarks.

\section{Blockchain technology-what is that about?}

As already highlighted, payment in cryptocurrencies does not need a centralised authority-namely, a government or a central financial bank. A peer-to-peer transaction is based on a computer code in which cryptographically secured data is exchanged. Wandhöfer (2017, p. 250) has compared this process to exchanging physical money. However, as Fulmer (2019, p. 166) has logically and systematically explained, beyond decentralisation, blockchain is also characterised by proof-of-work consensus, and practical immutability.

The question boils down to how transactions are confirmed and validated. Blockchain technology is based on the concept of the distributed ledger. The original moment of data creation (an online transaction) is recorded in the blockchain ledger forming the original block. This block and each subsequent transaction is then transmitted to all of the nodes (computers) participating in the blockchain. They perform the role of transaction validators. The blockchain becomes immutable, and it is possible to trace blocks back to the original entry. Thus, it would be difficult to falsify a transaction because all the previous transactions would have to be altered as well. Of course, the blockchain provides the users incentives to verify valid transactions since the block validation process requires enormous amounts of computing power. Cryptocurrency is a reward in return for providing computing power, and the engagement in calculations is called "mining". However, the miners are incentivised only for adding legitimate blocks to the chain. Trust between individuals about the validity of transactions is established through the process of solving complex computations, too difficult to tamper with. It is connected with the previously signalled proof-of-work concept, namely, the solutions to complex computations needed to validate a transaction (Fulmer, 
2019, pp. 167-171; Meth, 2019, pp. 7-9; Ruggiero, 2018, pp. 69-71; Zozaya et al., 2019, pp. 120-126).

As rightly pointed out by Zekos (2019, p. 6), virtual currency has value only because people believe that others will be willing to accept it in exchange for goods and services. In other words, the crux of the matter is that who is willing to accept the payment. ${ }^{2}$ The research question concerns finding out whether an employee can receive and accept remuneration in cryptocurrency under Polish legal regulations, especially in the context of uncertainty related to cryptocurrencies (the possibility of becoming a cybercrime victim; cryptocurrencies' fluctuations; the event of failure of the blockchain ledger; for some people, the lack of a centralised authority, such as government). Is the volenti non fit iniuria principle to be considered here, or should the protective function of labour law prevail?

\section{Cryptocurrency from the perspective of the employment relationship and civil law contracts}

According to English and Nezhadian (2017, p. 64), "[a]s Bitcoin and similarly designed cryptocurrencies evolve into a recognized medium of exchange for larger swaths of the world economy, an increasing number of people will earn income in the form of blockchain-based payments". In fact, there is evidence of the increasing worldwide popularity of cryptocurrency as a means of remuneration (Magas, 2018). Recently, for example, payment of remuneration in Bitcoin and other cryptocurrencies has been found legal in New Zealand (Beedham, 2019). In this article, we aim to highlight problems arising from such payments in the context of Polish law.

The only legal regulation expressly referring to virtual currency is the Act of 1 March 2018 on Counteracting Money Laundering and Financing of Terrorism (2018). In Article 2(2), point 26, it introduced the definition of "virtual currency". It is understood as a digital representation of value which is not:

a) A legal tender issued by the National Bank of Poland (NBP), a foreign central bank or any other public administration body;

b) An international settlement unit established by an international organisation and accepted by individual countries belonging to this organisation or cooperating with it;

${ }_{2}$ See coinmap.org for the map of all the cryptocurrency merchants in the world. 
c) Electronic money within the meaning of the Act of 19 August 2011 on Payment Services;

d) A financial instrument within the meaning of the Act of 29 July 2005 on Trading in Financial Instruments;

e) A bill of exchange or check;

and which is exchangeable in the course of trade for legal means of payment and accepted as a medium of exchange which may also be electronically stored or transferred or may be subject to e-commerce.

Clearly, the presented broad definition of a virtual currency embraces cryptocurrencies. Such an interpretation is confirmed, e.g., by the Regional Administrative Court in Łódź (Judgment I SA/£d 411/19). However, the question is whether wages can be paid in a virtual currency (cryptocurrency).

In this regard, it is worth noting that according to Article 227(1) of the Constitution of the Republic of Poland of 2 April 1997 (no. 78, item 483) and according to the Act of 29 August 1997 on the National Bank of Poland (no. 140, item 938 with amendments), the National Bank of Poland has the exclusive right to issue the currency of the Republic of Poland (Art. 4). Banknotes and coins based on zloty and grosze are the currency symbols of the Republic of Poland (Art. 31), and the currency issued by the National Bank of Poland is the legal tender in the Republic of Poland (Art. 32). It follows that virtual currency is not a legal tender in Poland. On the other hand, the International Labour Organisation's Protection of Wages Convention No. 95 (ILO, 1949), ratified by Poland, stipulates that wages payable in money shall be paid only in legal tender, and payment in the form of promissory notes, vouchers or coupons, or in any other form alleged to represent legal tender, shall be prohibited (Art. 3(1)). In short, the analysis of applicable law leads to the conclusion that wages in Poland cannot be paid in cryptocurrency because wages payable in money shall be paid only in legal tender, and cryptocurrency is not a legal tender in Poland. This is confirmed by Article 86, paragraph 2 of the Act of 26 June 1974 Labour Code (no. 24, item 141 with amendments), which introduces a general principle of payment of remuneration in cash (with only some exceptions).

Taking into account the above issues, the question about the ratio legis of such a provision should be considered. This is where the axiological approach to the analysis becomes most apparent as remuneration in the framework of an employment relationship has a special social significance since it constitutes a source of maintenance for everyone who provides his or her own labour to the employer. So, basically, remuneration for work performs 
a maintenance function. As pointed out by Walczak (2012, p. 120), the basic part of the remuneration should be reasonably stable and should not exhibit large fluctuations. Uncertainty related to cryptocurrencies constitutes grounds in support of the statement that they cannot be used for paying salaries. For example, due to the fear of coronavirus, "Bitcoin lost roughly $50 \%$ of its value in a day" (Bovaird, 2020). Depriving an employee of one-half of the value of the remuneration would be contrary to the protective function of labour law. Even if someone mines cryptocurrencies in the framework of an employment relationship, paying them in cryptocurrencies would mean passing the economic risk from the employer to the employee. Briefly speaking, remuneration enjoys legal protection consisting of, among others, limiting its non-cash payment.

Article 86, paragraph 2 of the Act of 26 June 1974 Labour Code allows, under certain conditions, partial non-cash payment of remuneration. The provision stipulates that remuneration is paid in cash, and partial non-cash payment of remuneration is allowed only when provided for in the labour law or in the collective labour agreement. ${ }^{3}$ Currently, in Poland, neither labour law nor collective labour agreements allow partial non-cash payment of remuneration in cryptocurrencies. Hypothetically, however, given that many crypto enthusiasts from all over the world are ready to be paid for work in cryptocurrencies (Magas, 2018), we can imagine a regulation introducing partial non-cash payment of remuneration in cryptocurrencies. One should remember, however, that there are some limitations in this regard imposed by Article 4(2) of the Protection of Wages Convention. That measure states that in cases in which partial payment of wages in the form of allowances in kind is authorised, appropriate measures shall be taken to ensure that: such allowances are appropriate for the personal use and benefit of the worker and his family, and the value attributed to such allowances is fair and reasonable. Due to the fluctuations of cryptocurrencies, the fulfilment of the second condition can only be determined after exchanging the cryptocurrency for zloty. But, as pointed out by Magas (2018), in many countries wages in cryptocurrencies are popular mainly inside the industry, i.e., among people with enormous salaries who, additionally, want to be paid this way.

Most often, in Poland, the regulations introduce, as partial non-cash

$3 \quad$ It corresponds to the provisions of the Protection of Wages Convention (Art. 4(1)), which sets forth that national laws or regulations, collective agreements or arbitration awards may authorise partial payment of wages in the form of allowances in kind in industries or occupations in which payment in the form of such allowances is customary or desirable because of the nature of the industry or occupation concerned. 
payment of remuneration, payment in kind in the form of goods produced by the employer (e.g., coal) or services rendered (e.g., electricity supply, free rail transport) (Wagner, 2017). It is correct to support the view that cryptocurrencies could come into play in this case. Unfortunately, the Polish legislator has not specified what part of the remuneration may be paid off in in-kind payments. According to Skoczyński (2008), it should be considered as a circumvention of the law if the part of the remuneration paid in kind significantly exceeds the part of the remuneration paid in cash. Sometimes, partial remuneration in kind is also treated as an additional benefit granted to employees on account of merely being in an employment relationship, rather than as part of the remuneration for work done (Prusinowski, 2018). There is little doubt that this function could be fulfilled by a virtual currency.

A similar dilemma concerning the utilisation of cryptocurrencies arises when it comes to a bonus due under an employment relationship. In Poland, a bonus shows the characteristics of remuneration and is treated as a remuneration component. For this reason, it is subject to the same rules as remuneration. In the light of all the foregoing considerations, we therefore conclude that limitations arising from Article 86, paragraph 2 of the Labour Code will be applicable also to the bonus.

The situation is different with regard to an award. Unlike bonus, under Polish employment law, an award is not treated as a remuneration component, so limitations related to remuneration do not apply to it. Thus, it must be found that there is no obstacle to paying an award (even in the full amount) in cryptocurrency (see also Tomanek, 2017, p. 583). This remains solely at the discretion of the employer. In this respect, it is also noteworthy that virtual currency is classified as a property value. Under the definition in Article 2(2), point 26 of the Act of 1 March 2018 on Counteracting Money Laundering and Financing of Terrorism, property values mean property rights or other movable property or real estate, means of payment, financial instruments within the meaning of the Act of 29 July 2005 on trading in financial instruments, other securities, foreign exchange values and virtual currencies.

Unlike the Labour Code, the Civil Code (1964, no. 16, item 93 with amendments) does not require that the remuneration resulting from civil law contracts should be paid in money. The only exception, which has been in force since 1 January 2017, concerns the minimum hourly remuneration in mandate and services contracts (17 Polish zloty in 2020). Remuneration in excess of the aforementioned limit may be paid in a different form, even 
cryptocurrencies. Remuneration resulting from contracts for specific work or agency contract can be paid in cryptocurrency in full since the minimum hourly remuneration does not apply to them.

Against the background of the above considerations, the question arises as regards the taxation of cryptocurrencies. Let us revisit here to the research question formulated at the beginning-namely, the situation in which somebody achieves revenue from cryptocurrency trading in the course of an economic activity, and employs a worker who is mining cryptocurrencies in the framework of an employment relationship or a services contract. Let us also imagine that this worker receives an award which is paid in cryptocurrency (employment relationship) or remuneration in excess of the minimum hourly remuneration, paid in cryptocurrency as well (services contract). The following question arises: what are the rules of taxation, first, if one achieves revenue from cryptocurrency trading and, second, if one is paid in cryptocurrency under an employment contract or a services contract.

\section{Cryptocurrency from the perspective of tax law}

The new tax regulations in force in Poland since 1 January 2019 have introduced some changes when it comes to tax acts and virtual currencies. The cases in point are the Act of 26 July 1991 on Personal Income Tax (no. 80, item 350 with amendments) and the Act of 15 February 1992 on Corporate Income Tax (no. 21, item 86 with amendments).

It should be clearly explained that, pursuant to these Acts a virtual currency means a virtual currency within the meaning of Article 2(2), point 26 of the Act on Counteracting Money Laundering and Financing of Terrorism (the definition is given above). Thus, comments regarding the Act on Personal Income Tax are also relevant to the Act on Corporate Income Tax.

Analysing the situation above, suggesting an award or remuneration is paid in cryptocurrency under an employment contract or a services contract, we should indicate that the income tax is calculated from the taxable base. This means that if a taxable base in Polish zloty is less than 85,528, the tax amounts to $17 \%$ (minus the tax-reducing amount), and if a taxable base in Polish zloty is above 85,528 , the tax amounts to $14,539.76$ zloty $+32 \%$ of any surplus over 85,528 zloty (minus the tax-reducing amount) (Art. 27(1) of the Act on Personal Income Tax). In other words, the value of the cryptocurrency 
thus obtained is taxed on a general basis, that is to say, by analogy, like the remuneration paid in money under an employment contract or a services contract.

A different picture emerges in a case in which one achieves revenue from cryptocurrency trading when virtual currency is mined for the person's own account. Currently, revenues from cryptocurrency trading are classified as revenues from money capital and revenues from capital gains. More specifically, Article 17(1), point 11 of the Act on Personal Income Tax stipulates that revenue from money capital shall include revenue from the disposal for valuable consideration of a virtual currency, and Article $7 b(1)$, letter $f$ of the Act on Corporate Income Tax sets out that revenues from capital gains shall include revenue from the exchange of a virtual currency for legal tender, goods, services or property rights other than a virtual currency or from the settlement of other liabilities with a virtual currency (see also the abovementioned judgment of 19 November 2019 of the Regional Administrative Court in Łódź). It is a serious reform, especially in the light of the fact that by the end of 2018, financial gain from cryptocurrency trading was classified as a property right (Krysiak et al., 2019, pp. 25-26, 30; Prokurat, 2015, pp. 26-28; Słapczyński, 2019, pp. 33-35). Due to the lack of relevant legal regulations, such a solution was based on a uniform administrative jurisprudence, e.g., judgment of the Supreme Administrative Court of 6 March 2018, II FSK 488/16. Consequently, under the previous regime a progressive tax scale was applicable. This means that the income tax was calculated from the taxable base, namely if a taxable base in Polish zloty was less than 85,528 , the tax amounted to $18 \%{ }^{4}$ (minus the tax-reducing amount), and if a taxable base in Polish zloty was above 85,528 , the tax amounted to $15,395.04$ Polish zloty $+32 \%$ of any surplus over 85,528 Polish zloty (minus the tax-reducing amount) (Art. 27(1) of the Act on Personal Income Tax). It should also be added that previously the loss was accounted for and now such practices are prohibited. Therefore, if an investment ends in failure, a taxpayer is forced to bear the full economic cost of the loss generated (see Jamroży et al., 2019, pp. 5-6).

Doubts arise as to whether the classification of a virtual currency as a property right was the most suitable. We should take into consideration that property rights are related to the rightholder's economic interests. They are connected with his property, are characterised by marketability (can be traded) and have a specific asset value. It turns out that not in every situation,

4 Since 1 January 2019 , it has been reduced to $17 \%$. 
the abovementioned features can be directly related to cryptocurrencies. This is, firstly, due to the fact that the value of cryptocurrencies can only be estimated properly in the case of their sale. Secondly, the purchase of cryptocurrencies and their subsequent sale are associated with the volatility of their value over time, which, in turn, makes the achievement of income uncertain. Thirdly, the significant volatility of cryptocurrency value is independent of the taxpayer and conditioned by market factors. All these arguments indicate that conceptually the cryptocurrency trading benefits are closer to revenues from money capital and revenues from capital gains (see Krysiak et al., 2019, p. 26).

Importantly, under the Act on Personal Income Tax, revenues from cryptocurrency trading are classified as revenues from money capital even if a taxpayer earns revenue from cryptocurrency trading in the context of the pursuit of an economic activity.

The new Article 17(1), letter $\mathrm{f}$ of the Act on Personal Income Tax establishes a definition of the disposal for valuable consideration of a virtual currency. It shall mean the exchange of a virtual currency for legal tender, goods, services or property rights other than a virtual currency or the settlement of other liabilities with a virtual currency.

The Act on Personal Income Tax states that revenue from money capital shall include revenue from the disposal for valuable consideration of a virtual currency (Art. 17(1), point 11), and that income tax on income earned from the disposal for valuable consideration of virtual currencies shall be $19 \%$ of the income earned (Art. 30b(1a)). The legislator specifies that income from the disposal for valuable consideration of virtual currencies shall be the difference in a given tax year between the sum of the revenue earned from the disposal for valuable consideration of virtual currencies and the tax-deductible expenses (Art. 30b(1b)).

As expected, in the light of the Act on Corporate Income Tax, revenue from the exchange of a virtual currency for legal tender, goods, services or property rights other than a virtual currency or from the settlement of other liabilities with a virtual currency shall be considered revenues from capital gains (Art. $7 b(1)$, point 6, letter $\mathrm{f}$ ). Income tax on income earned from the disposal against payment of virtual currencies shall be $19 \%$ of the income earned (Art. $22 \mathrm{~d}(1)$ ). Income from the disposal against payment of virtual currencies shall be the difference in a given fiscal year between the sum of the revenue and the tax-deductible expenses (Art. $22 \mathrm{~d}(1)$ ). It is worth stressing 
that income from the disposal against payment of virtual currencies shall not be combined with other income (revenue) of a given taxable person.

The new regulation also embraces tax-deductible expenses. As is apparent from the Act on Personal Income Tax, the tax-deductible expenses related to the disposal for valuable consideration of virtual currency constitute documented expenses incurred directly for the acquisition of virtual currency and costs related to the disposal of virtual currency. The abovementioned tax-deductible expenses shall be deducted in the tax year in which they were incurred. However, the surplus of the tax-deductible expenses in relation to the revenue from the disposal for valuable consideration of virtual currency, earned in a given tax year, shall increase the tax-deductible expenses for the disposal for valuable consideration of virtual currency incurred in the next tax year (Art. 22(14-16). The same considerations are valid concerning the Act on Corporate Income Tax (Art. 15(11-13)).

Interestingly, the exchange of a virtual currency for another virtual currency does not bring about consequences from the point of view of income tax.

Last but not least, as regards cryptocurrency trading in the context of the pursuit of an economic activity, we should refer to the Council Directive 2006/112/EC of 28 November 2006 on the common system of value added tax (hereinafter: the VAT Directive). In accordance with its provisions, Member States shall exempt transactions, including negotiation, concerning currency, bank notes and coins used as legal tender, with the exception of collectors' items, that is to say, gold, silver or other metal coins or banknotes which are not normally used as legal tender or coins of numismatic interest (Council Directive 2006/112/EC, Art. 135(1), letter e). Following the interpretation of the Court of Justice of the European Union (the judgment of 22 October 2015 in Skatteverket v. David Hedqvist [2015]), Article 135(1), letter e of the VAT Directive means that the supply of services which consist of the exchange of traditional currencies for units of the 'bitcoin' virtual currency and vice versa, performed in return for a payment of a sum equal to the difference between, on the one hand, the price paid by the operator to purchase the currency and, on the other hand, the price at which he sells that currency to his clients, are transactions exempt from VAT, within the meaning of that provision.

In this judgement, the Court of Justice of the European Union has also interpreted Article 2(1), letter c, according to which the supply of services for consideration within the territory of a Member State by a taxable 
person acting as such shall be subject to VAT. The Court ruled that Article $2(1)$, letter $\mathrm{c}$ of the VAT Directive must be interpreted as meaning that transactions which consist of the exchange of traditional currency for units of the 'bitcoin' virtual currency and vice versa, in return for a payment of a sum equal to the difference between, on the one hand, the price paid by the operator to purchase the currency and, on the other hand, the price at which he sells that currency to his clients, constitute the supply of services for consideration within the meaning of that Article.

The Court of Justice of the European Union has explained that Article 135(1), letter $\mathrm{d}^{5}$ and $\mathrm{f}$ of the VAT Directive must be interpreted as meaning that such a supply of services does not fall within the scope of application of those provisions.

Case C-264/14, Skatteverket v. David Hedqvist [2015] has impacted the approach to the VAT problem in Poland. Before the judgment of 22 October 2015 there had only been some interpretations of the Directors of the Tax Chambers, e.g., the interpretation of the Director of the Tax Chamber in Katowice of 21 June 2013, no. IBPP2/443-258/13/ICz, according to which brokering the purchase and sale of Bitcoin certificates does not constitute intermediation in financial services. Bitcoin is not a currency recognised as a legal tender in the light of Polish law and EU directives; therefore, Bitcoin brokerage is not a financial service. Thus, services consisting in the purchase and sale of Bitcoin certificates or intermediation in the performance of these services are not subject to VAT exemption (Letter of Tax Chamber in Katowice IBPP2/443-258/13/Icz). A similar interpretation was given by the Director of the Tax Chamber in Łódź on 7 April 2014 (Letter of Tax Chamber in Łódź IPTPP2/443-52/14-6/IR). Since the Skatteverket v. David Hedquist case, activities consisting in the purchase and sale of virtual currency have been exempt from VAT pursuant to Article 43(1), point 7 of the Act of 11 March 2004 on Goods and Services Tax (no. 54, item 535 with amendments). ${ }^{6}$

$5 \quad$ Member States shall exempt transactions, including negotiation, concerning deposit and current accounts, payments, transfers, debts, cheques and other negotiable instruments, but excluding debt collection.

$6 \quad$ It states that transactions, including agency, concerning currency, banknotes and coins used as legal tender, excluding banknotes and coins which are collectors' items, as such considered to be coins of gold, silver or other metal and banknotes, which are not normally used as legal tender or are of a numismatic value, are exempt from the value added tax. 


\section{Conclusion}

The views on the blockchain technology and cryptocurrencies are ambiguous. Opponents of the virtual currency treat Bitcoin as a financial pyramid or a speculative bubble that must burst one day. On the other hand, proponents of this form of payment argue that Bitcoin is a revolution and for the world of finance it is what an e-mail was for traditional postal mail (Pasternak, 2017, p. 77). Without seeking to resolve this debate, we have focused on the functioning of the blockchain technology and some urgent legal problems.

The conclusions, drawn from the conducted research, help to confirm the veracity of the research hypothesis that preventing payment of salaries in full in cryptocurrencies constitutes a fulfilment of the protective function of labour law. Remuneration for work is a main (and often sole) source of maintenance for the employee and his or her family-therefore it is covered by the legal protection. The analysis of law in Poland reveals that wages payable in money shall be paid only in legal tender, and cryptocurrency is not a legal tender in the said country. Taking into account the risk involved in cryptocurrencies, this solution should be considered correct. However, there is a provision in the Labour Code according to which partial non-cash payment of remuneration is allowed only when provided for in the labour law or in the collective labour agreement. In fact, sometimes collective labour agreements introduce, as partial non-cash payment of remuneration, payment in kind in the form of goods produced or services rendered by the employer. Thus, the law creates the possibility of including in a collective labour agreement a clause allowing the employer to realise partial noncash payment of remuneration in cryptocurrency (e.g., inside the blockchain industry). It is also possible to introduce a similar provision to the labour law, but the Polish legislator has never adopted such a measure.

The study has also argued that limitations arising from Article 86, paragraph 2 of the Labour Code are applicable to the bonus, which is designed as a remuneration component under Polish labour law. However, a different conclusion can be drawn with regard to an award which can be paid in cryptocurrency also in the full amount.

As regards the Civil Code, generally it does not require that the remuneration resulting from civil law contracts should be paid in money. There is, however, an exception concerning the minimum hourly remuneration in mandate and 
services contracts, i.e., 17 Polish zloty in 2020. Remuneration in excess of this limit may also be paid in cryptocurrencies.

The validity of the second research hypothesis is also determined. It is conceptually more convincing to classify revenues from cryptocurrency trading as revenues from money capital and revenues from capital gains than as property rights. Property rights are associated with the rightholder's economic interests. Clearly, their marketability and the assignment of a specific asset value do not coincide with the nature of cryptocurrencies. For this reason, the new tax regulations in force in Poland since 1 January 2019 should be positively welcomed. This change of approach has its consequences. Under the previous regime, the income tax was calculated on the taxable base. If a taxable base in Polish zloty was less than 85,528, the tax amounted to $18 \%$ (minus the tax-reducing amount), and if a taxable base in Polish zloty was above 85,528, the tax amounted to 15,395.04 zloty $+32 \%$ of any surplus above 85,528 zloty (minus the tax-reducing amount). On the other hand, now the income tax on income earned from the disposal for valuable consideration of virtual currencies shall be $19 \%$ of the income earned. Previously the loss was accounted for, and now it is banned to do so.

It should be noted, however, that if an award or remuneration is paid in cryptocurrency under an employment contract or a services contract, the value of the cryptocurrency is taxed on a general basis, by analogy with the taxation of the remuneration paid in money under an employment contract or a services contract.

Aneta Tyc is a doctor of law and an assistant professor at the Department of Labour Law of the Faculty of Law and Administration, University of Łódź. Currently, she is conducting research on cryptocurrency from the perspective of employment law, labour rights in the context of global trade, and self-employment against the legal-comparative background.

Robert Siuciński is an assistant at the Institute of Comparative Administrative Procedure, the Faculty of Law and Administration, University of Łódź. Currently, he is conducting research on cryptocurrency from the perspective of tax law, and services conference as a form of administrative proceedings. 


\section{References}

Act on Corporate Income Tax, Dziennik Ustaw [Journal of Laws], no. 21, item 86 with amendments, 15.2.1992.

Act on Counteracting Money Laundering and Financing of Terrorism, Dziennik Ustaw [Journal of Laws], item 723 with amendments, 1.3.2018.

Act on Goods and Services Tax, Dziennik Ustaw [Journal of Laws], no. 54, item 535 with amendments, 11.3.2004.

Act on Personal Income Tax, Dziennik Ustaw [Journal of Laws], no. 80, item 350 with amendments, 26.7.1991.

Act on the National Bank of Poland, Dziennik Ustaw [Journal of Laws], no. 140, item 938 with amendments, 29.8.1997.

Appukuttan Nair, D. (2019), 'The bitcoin innovation, crypto currencies and the Leviathan,' Innovation \& Development, vol. 9, no. 1, pp. 85-103. https://doi.org/10.1080/2157930X.2018.1502249

Beedham, M. (2019), 'New Zealand greenlights Bitcoin salary regulation - but it's still a bad idea,' The Next Web, 12 August. Retrieved from https://thenextweb.com/hardfork/2019/08/12/new-zealand-bitcoinsalary-regulation-bad-idea/ [accessed 18 Jan 2020]

Bovaird, C. (2020), 'Bitcoin lost roughly $50 \%$ of its value in a day,' Forbes, 12 March. Retrieved from https://www.forbes.com/sites/ cbovaird/2020/03/12/bitcoin-lost-roughly-50-of-its-value-in-aday/\#3b6427443056 [accessed Mar 2020]

Civil Code, Dziennik Ustaw [Journal of Laws], no. 16, item 93 with amendments, 23.4.1964.

CoinMarketCap (2020), 'All cryptocurrencies,' 14 March. Retrieved from https://coinmarketcap.com/all/views/all/ [accessed 14 Mar 2020]

Constitution of the Republic of Poland, Dziennik Ustaw [Journal of Laws], no. 78, item 483, 2.4.1997.

Council Directive 2006/112/EC of 28 November 2006 on the common system of value added tax, $O J$ L 347, 11.12.2006, pp. 1-118.

English, S. M. \& Nezhadian, E. (2017), 'Conditions of full disclosure: the blockchain remuneration model,' 2017 IEEE European Symposium on Security and Privacy Workshops (EuroS\&PW), pp. 64-67.

https://doi.org/10.1109/EuroSPW.2017.52

Fulmer, N. (2019), 'Exploring the Legal Issues of Blockchain Applications,' Akron Law Review, vol. 52, no. 1, pp. 161-192.

ILO (1949), Protection of Wages Convention, no. 95, International Labour Organisation. Retrieved from https://www.ilo.org/dyn/normlex/en/f? 
p=NORMLEXPUB:12100:0::NO::P12100_INSTRUMENT_ID:312240 [accessed 18 Jan 2020]

Jamroży, M. \& Wiśniewski, Ł. (2019), 'X Debata Podatkowa. Opodatkowanie obrotu walutami opartymi o technologię blockchain,' Przegląd Podatkowy, no. 4, pp. 5-6.

Judgment of the Regional Administrative Court in Łódź, I SA/Łd 411/19, LEX no. $2761356,19.11 .2019$.

Judgment of the Supreme Administrative Court, II FSK 488/16, 6.3.2018. Retrieved from http://orzeczenia.nsa.gov.pl/doc/C8296DC8B9 [accessed 18 Jan 2020]

Krysiak, C.; Widzyk, D. \& Janiszewski, P. (2019), 'Opodatkowanie transakcji wirtualnych,' Przegląd Podatkowy, no. 3, pp. 25-35.

Labour Code, Dziennik Ustaw [Journal of Laws], no. 24, item 141 with amendments, 26.6.1974.

Letter of Tax Chamber in Katowice IBPP2/443-258/13/ICz, 21.6.2013. Retrieved from https://sip.lex.pl/orzeczenia-i-pisma-urzedowe/ pisma-urzedowe/ibpp2-443-258-13-icz-pismo-wydane-przez-izbaskarbowa-w-184744857 [accessed 4 Mar 2020]

Letter of Tax Chamber in Łódź IPTPP2/443-52/14-7/16-S/IR, 11.7.2016. Retrieved from https://sip.lex.pl/orzeczenia-i-pisma-urzedowe/ pisma-urzedowe/iptpp2-443-52-14-7-16-s-ir-pismo-wydane-przezizba-184868478 [accessed 4 Mar 2020]

Magas, J. (2018), 'Blockchain and crypto in the labor market: overview of salaries, taxes and the most in-demand jobs,' Cointelegraph, 6 December. Retrieved from https://cointelegraph.com/news/blockchainand-crypto-in-the-labor-market-overview-of-salaries-taxes-and-themost-in-demand-jobs [accessed 18 Jan 2020]

Malherbe, L.; Montalban, M.; Bédu, N. \& Granier, C. (2019), 'Cryptocurrencies and blockchain: opportunities and limits of a new monetary regime,' International Journal of Political Economy, vol. 48, pp. 127-152. https://doi.org/10.1080/08911916.2019.1624320

Meth, M. (2019), Blockchain in Libraries, Library Technology Reports, vol. 55 , no. 8.

Nakamoto, S. (2008), 'Bitcoin: a peer-to-peer electronic cash system,' bitcoin.org. Retrieved from https://bitcoin.org/bitcoin.pdf [accessed 17 Jan 2020]

Pasternak, Ł. (2017), 'Kryptowaluta i pieniądz wirtualny jako przedmiot przestępstwa z art. 310 § 1 k.k.,' Prokuratura i Prawo, no. 4, pp. 77-94.

Prokurat, J. (2015), 'Podatkowe aspekty obrotu wirtualnymi walutami,' Przegląd Podatkowy, no. 3, pp. 24-37. 
Prusinowski, P. (2018), 'Komentarz do artykułu 86,' in K. W. Baran (ed.) Kodeks pracy. Komentarz, Lex, Warsaw: Wolters Kluwer Polska.

Ruggiero, Jr. M. A. (2018), 'Cryptocurrencies from the inside out,' Modern Trader, no. 544, pp. 67-71.

Skatteverket v. David Hedqvist [2015], Judgment of the Court of Justice of the European Union, C-264/14, 22.10.2015.

Skoczyński, J. (2008), 'Komentarz do artykułu 86,' in Z. Salwa (ed.), Kodeks pracy. Komentarz, Lex, Warsaw: Wolters Kluwer Polska.

Słapczyński, T. (2019), 'Blockchain technology and cryptocurrencies - legal and tax aspects,' ASEJ - Scientific Journal of Bielsko-Biala School of Finance and Law, vol. 23, no. 1, pp. 31-36. https://doi. org/10.5604/01.3001.0013.2653

Taleb, N. (2019), 'Prospective applications of blockchain and Bitcoin cryptocurrency technology,' TEM Journal, vol. 8, no. 1, pp. 48-55. https://doi.org/10.18421/TEM81-06

Tomanek, B. (2017), 'Wypłata wynagrodzenia w wirtualnej walucie bitcoin,' Monitor Prawa Pracy, no. 11, pp. 582-585.

Wagner, B. (2017), 'Komentarz do artykułu 86,' in L. Florek (ed.) Kodeks pracy. Komentarz, Lex, Warsaw: Wolters Kluwer Polska.

Walczak, K. (2012), 'Funkcje wynagrodzeń w społecznej gospodarce rynkowej - teoria i praktyka,' Studia z zakresu prawa pracy i polityki społecznej, Cracovia Annus MMXII, pp. 109-125.

Wandhöfer, R. (2017), 'The future of digital retail payments in Europe: A place for digital cash?' Journal of Payments Strategy \& Systems, vol. 11, no. 3, pp. 248-258.

Zekos, G. I. (2019), Economics and Legal Understanding of Virtual Currencies, Banking \& Financial Services Policy Report, vol. 38, no. 8.

Zozaya, C.; Incera, J. \& Franzoni, A. L. (2019), 'Blockchain: un tutorial,' Estudios, vol. 17, no. 129, pp. 113-126. https://doi.org/10.5347/0185 6383.0129 .000294417 